In cooperation with the U.S. Forest Service

\title{
Delineation of Landform and Lithologic Units for Ecological Landtype-Association Analysis in Glacier Bay National Park, Southeast Alaska
}

Scientific Investigations Report 2008-5183 
This page left intentionally blank. 


\section{Delineation of Landform and Lithologic Units for Ecological Landtype-Association Analysis in Glacier Bay National Park, Southeast Alaska}

By David A. Brew

In cooperation with the U.S. Forest Service

Scientific Investigations Report 2008-5183 


\section{U.S. Department of the Interior DIRK KEMPTHORNE, Secretary}

\section{U.S. Geological Survey \\ Mark D. Myers, Director}

U.S. Geological Survey, Reston, Virginia: 2008

This report and any updates to it are available online at:

http://pubs.usgs.gov/sir/2008/5183/

For product and ordering information:

World Wide Web: http://www.usgs.gov/pubprod

Telephone: 1-888-ASK-USGS

For more information on the USGS — the Federal source for science about the Earth, its natural and living resources, natural hazards, and the environment:

World Wide Web: http://www.usgs.gov

Telephone: 1-888-ASK-USGS

Any use of trade, product, or firm names is for descriptive purposes only and does not imply endorsement by the U.S. Government.

Although this report is in the public domain, permission must be secured from the individual copyright owners to reproduce any copyrighted materials contained within this report.

Suggested citation:

Brew, D.A., 2008, Delineation of landform and lithologic units for ecological landtype-association analysis in Glacier Bay National Park, southeast Alaska: U.S. Geological Survey, Scientific Investigations Report 2008-5183, 7 p. [http://pubs.usgs.gov/sir/2008/5183/].

Cataloging-in-publication data are on file with the Library of Congress (http://www.loc.gov/).

Produced in the Western Region, Menlo Park, California

Manuscript approved for publication, October 3, 2008

Text edited by Tracey Suzuki

Layout by David R. Jones 


\section{Contents}

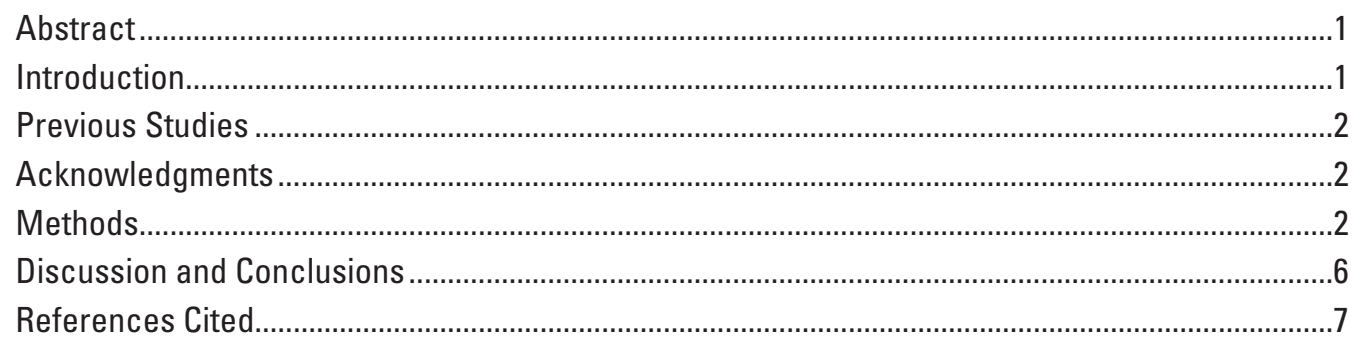

\section{Figures}

1. Map showing Glacier Bay National Park And Preserve and nearby Kootznahoo Wilderness Area (Admiralty Island), southeast Alaska... $\ldots 1$

2. A generalized schematic of the ecological hierarchy for southeast Alaska..................................

3. Map showing bedrock-lithologic units in Glacier Bay National Park, southeast Alaska...............

4. Map showing landform units in Glacier Bay National Park, southeast Alaska .............................

\section{Tables}

1. Glacier Bay National Park landtype-association analysis components, southeast Alaska .........5

2. Codes and brief descriptions of bedrock-lithologic units used in this report, Glacier Bay National Park, southeast Alaska.

3. Codes and brief descriptions of the landform classification units used in this report, Glacier Bay National Park, southeast Alaska. 
This page left intentionally blank. 


\title{
Delineation of Landform and Lithologic Units for Ecological Landtype-Association Analysis in Glacier Bay National Park, Southeast Alaska
}

\author{
By David A. Brew
}

\section{Abstract}

Landform and generalized bedrock lithologic units have been delineated for ecological landtype association analysis in Glacier Bay National Park in southeast Alaska (as the Park boundaries were defined before the 1971 Alaska National Interest Lands expansion).

Related U.S. Forest Service efforts have covered (1) the whole region at coarse ecological- unit scale, including domains, divisions, provinces, sections, and subsections; and (2) small parts the region at subsection scale. These small parts are generally forest-covered shoreline to timberline areas with relatively subdued topography, extensive bedrock exposures, and no active glaciers. The detailed studies established that the combination of landform and bedrocklithologic information was a good indicator of ecosystem productivity and types of plant communities.

This study of Glacier Bay National Park covers areas similar to those of the detailed studies but also includes a large proportion of high (15,300 feet), glacier-clad alpine terrain and large, active-valley glacier systems. This terrain reflects (1) the orographic and microclimatic effects associated with the high-altitude barrier that is the Fairweather Range part of the St. Elias Mountains and its rapidly retreating glaciers, and (2) the geologic, tectonic, and erosional history of this range.

In this study, landforms were classified - by using topographic maps and personal experience - into eight categories similar to those used by the U.S. Forest Service. The 90 bedrock-lithologic units on the current Glacier Bay geologic map were classified into 13 generalized lithologic units corresponding exactly to those used by the U.S. Forest Service. Incomplete storm-track, storm-intensity, and limited climatic information have also been compiled.

\section{Introduction}

There is an ongoing concerted effort in the United States to define ecosystems and their components (Cleland and others, 1997). Much of the impetus comes from land management needs at the Federal, State, and local levels. Among these is the current U.S. Geological Survey (USGS) emphasis on ecosystems (Myers and others, 2007). Other impetuses come from the desire to identify ecosystems that require immediate protection to preserve the ecological community representation and diversity of North America. Cleland and others (1997) note that basic information about the nature and distribution of ecosystems is required for ecosystem management, as well as for better understanding of ecological patterns and processes and the interactions of social, physical, and biological systems. Among the current efforts by the USGS and the U.S. Forest Service (USFS) is systematic compilation of ecological information from the World Heritage Site, which includes the Wrangell-St. Elias, Kluane, Tatshenshini-Alsek, and Glacier Bay Parks and the Kootznoowoo Wilderness Area (on Admiralty Island, fig. 1). All of these areas are shown on

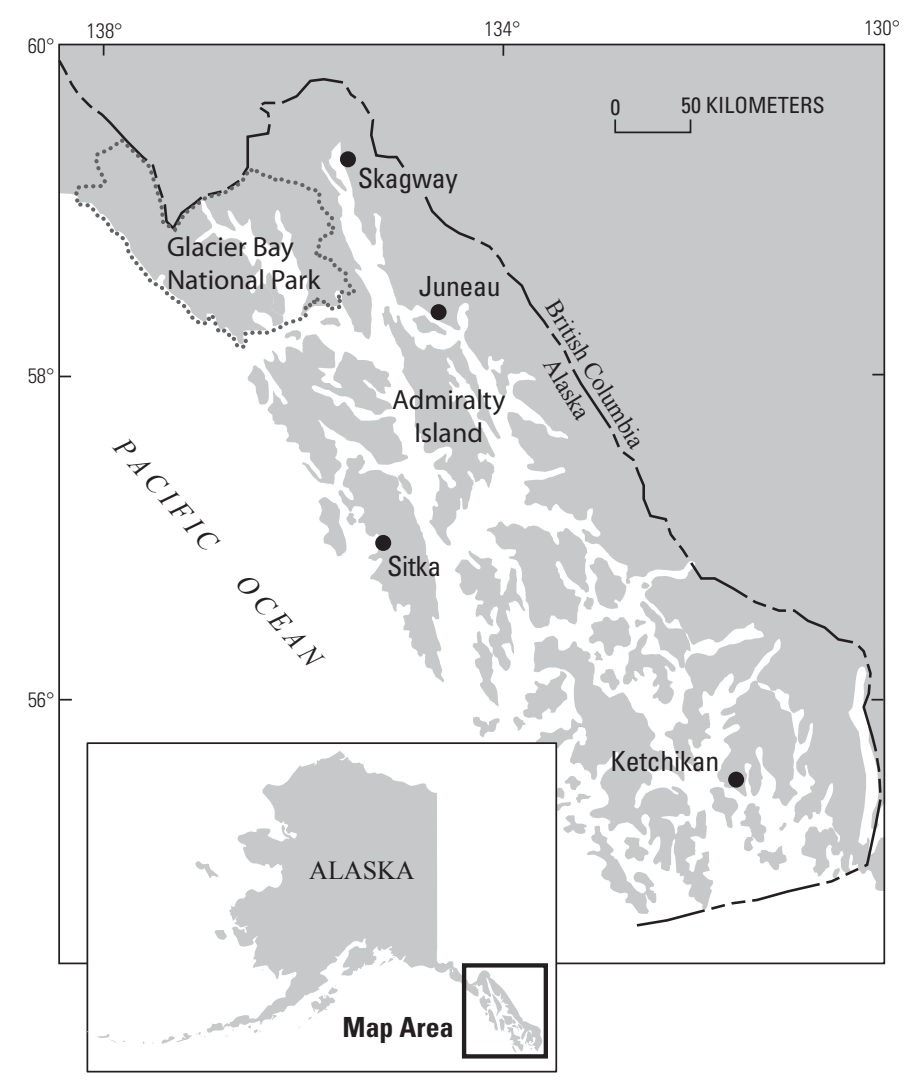

Figure 1. Map showing Glacier Bay National Park and Preserve and nearby Kootznahoo Wilderness Area (Admiralty Island), southeast Alaska. 
a shaded-relief topographic map of the whole World Heritage Site (Labay and Wilson, 2004) and part of the bedrock geology of the region has been published (Richter and others, 2007; Brew, 1997). This study contributes information previously not available for Glacier Bay National Park (GBNP) as it was defined before the 1971 Alaska National Interest Lands Act (ANILCA) expanded the Park's boundaries.

\section{Previous Studies}

Ecosystems are classified and mapped according to the "National Hierarchical Framework of Ecological Units" (Cleland and others, 1997). The hierarchy is designed to produce a nested set of ecological-unit maps, with the units at each level nesting upwards to constitute the next higher level. The framework of Cleland and others (1997) defines (from highest to lowest) the following levels: (1) domain, (2) division, (3) province, (4) section, (5) subsection, (6) landtype association, (7) landtype, and (8) landtype phase. The generalized classification used in this study follows this scheme and is intended to emphasize the landtype-association level (fig. 2).

An ecological-subsection map for all of southeast Alaska has been produced through the joint efforts of the USFS, the U.S. National Park Service, the USGS, and the British Columbia Ministry of Environment-Lands and Parks (Nowacki and others, 2001). This subsection map can be used as a basis for further studies and delineation of the landtype associations and

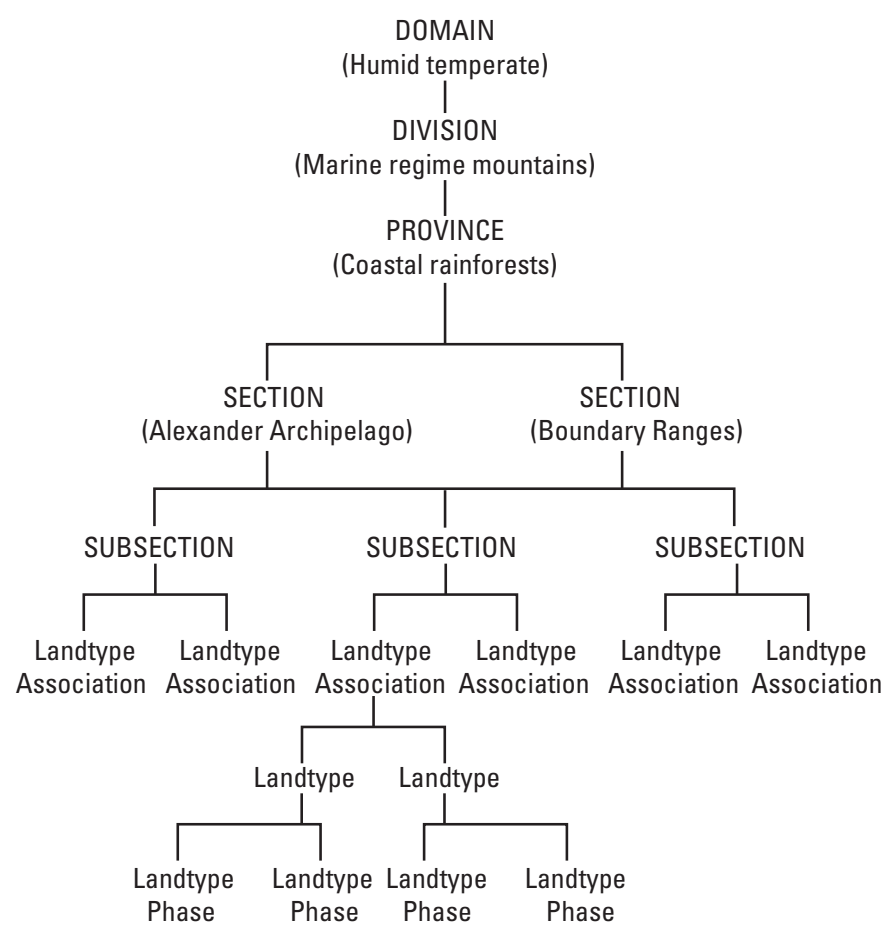

Figure 2. A generalized schematic of the ecological hierarchy for southeast Alaska (courtesy of Greg Nowacki, U.S. Forest Service, written comm., 2007; Nowacki and others, 2001, 2002 ). landtypes discussed in this report. Some of the specific topics discussed here were summarized by Brew (2000). The context of this southeast Alaska subsection map includes the general ecosystem studies of all of Alaska reported by Nowacki and others (2002) and by Spencer and others (2002). They divided GBNP was into three sections: (1) the Gulf of Alaska section along the western coastal strip, (2) the Chugach-St. Elias Mountains section of the high interior, and (3) the Alexander Archipelago surrounding Glacier Bay proper. The first of these divisions is readily recognizable on figure 3 . The boundary between the latter two divisions is that between glacier-covered mountains to the northwest and bare (or less-glacier covered) mountains to the southeast (fig. 4). Shephard and Brock (2002) studied the landtype associations of the Yakutat Foreland to the northwest of the present study area. The landtype associations that they identify correspond mostly to the more generalized "Sedimentary-Quaternary" unit (fig. 3) and to the "Plains" and "Surficial-deposit-filled glacially eroded valleys" unit (fig. 4).

The surficial deposits in the gap between the present study area and the Yakutat study area of Shephard and Brock (2002) were studied by G. Plafker (unpub. data, 2002).

\section{Acknowledgments}

The author is indebted to both his 1966 and 1975-1977 field-mapping colleagues and to all of the other field geologists who preceded us in the geologic study of the Park. Greg Nowacki and Mike Shephard of the USFS provided stimulating discussions at various times. Both Nowacki and Greg Streveler of Icy Strait Environmental Services Co., Gustavus, Alaska, provided very helpful technical reviews and additional information.

\section{Methods}

A comprehensive study of the landtype associations and landtypes in GBNP would include more than the bedrock and landform components described here. All of the components considered in this study are given in table 1. As described below, only bedrock geology and landform analysis are used in the present study. Classification schemes for vegetation zones and for storm zones and intensities were also developed as part of this analysis and were used in preliminary studies that are not reported here.

Everett Kissinger (USFS; written comm., 1997) developed an approach to ecosystem delineation for southeast Alaska that combined bedrock-geologic and landform data to define polygons that have, or may have, ecologic significance. Specifically, Kissinger utilized a bedrock-geologic map from a USGS study (Brew and others, 1984) together with a simplified version of the Forest Service Alaskan landform-classification scheme (USFS, 1996) to delineate moderate-size polygons on Kuiu Island in southeast Alaska (fig. 1). Kissinger's 


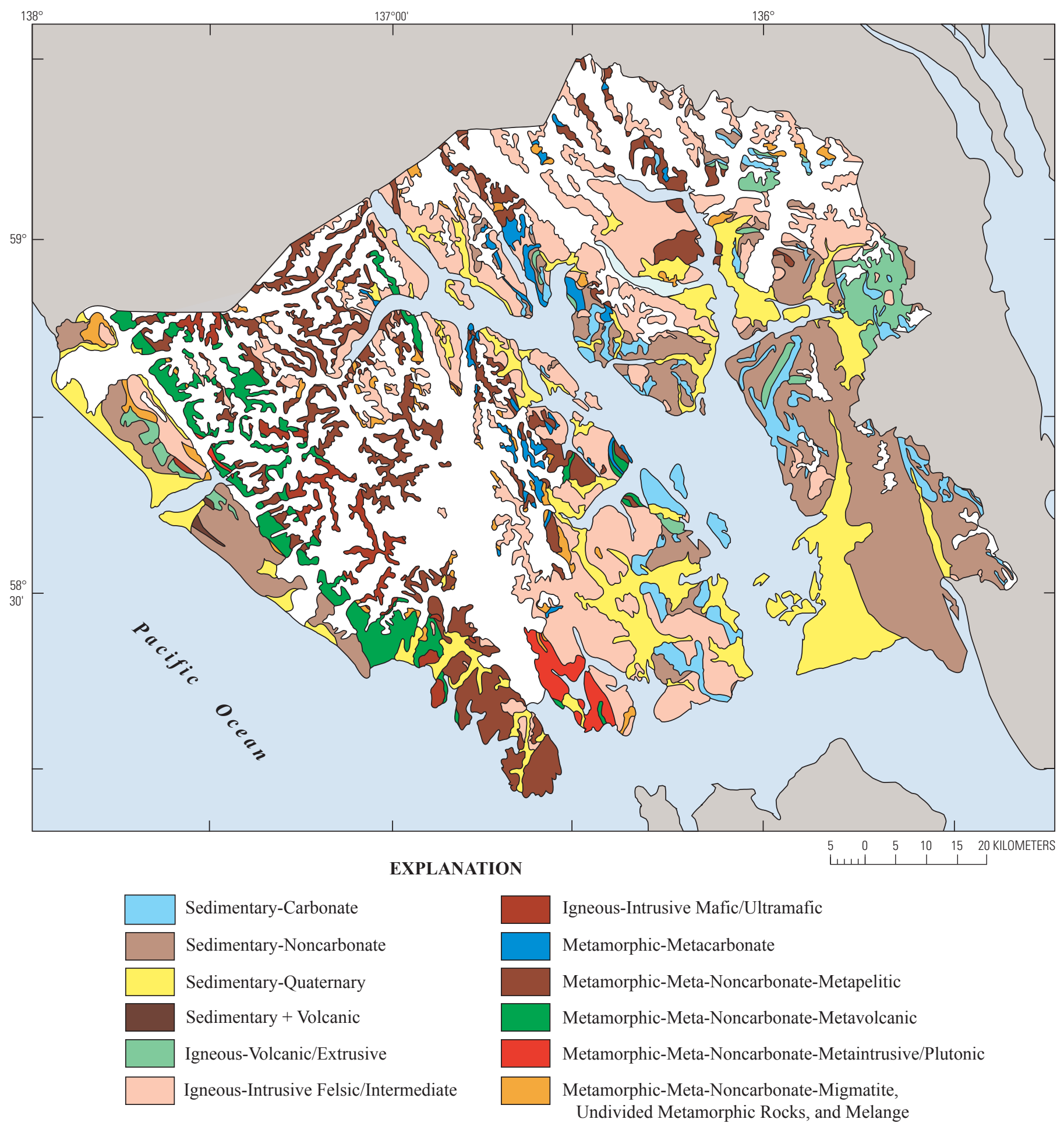

Figure 3. Map showing bedrock-lithologic units in Glacier Bay National Park, southeast Alaska (see fig. 1 for location). 


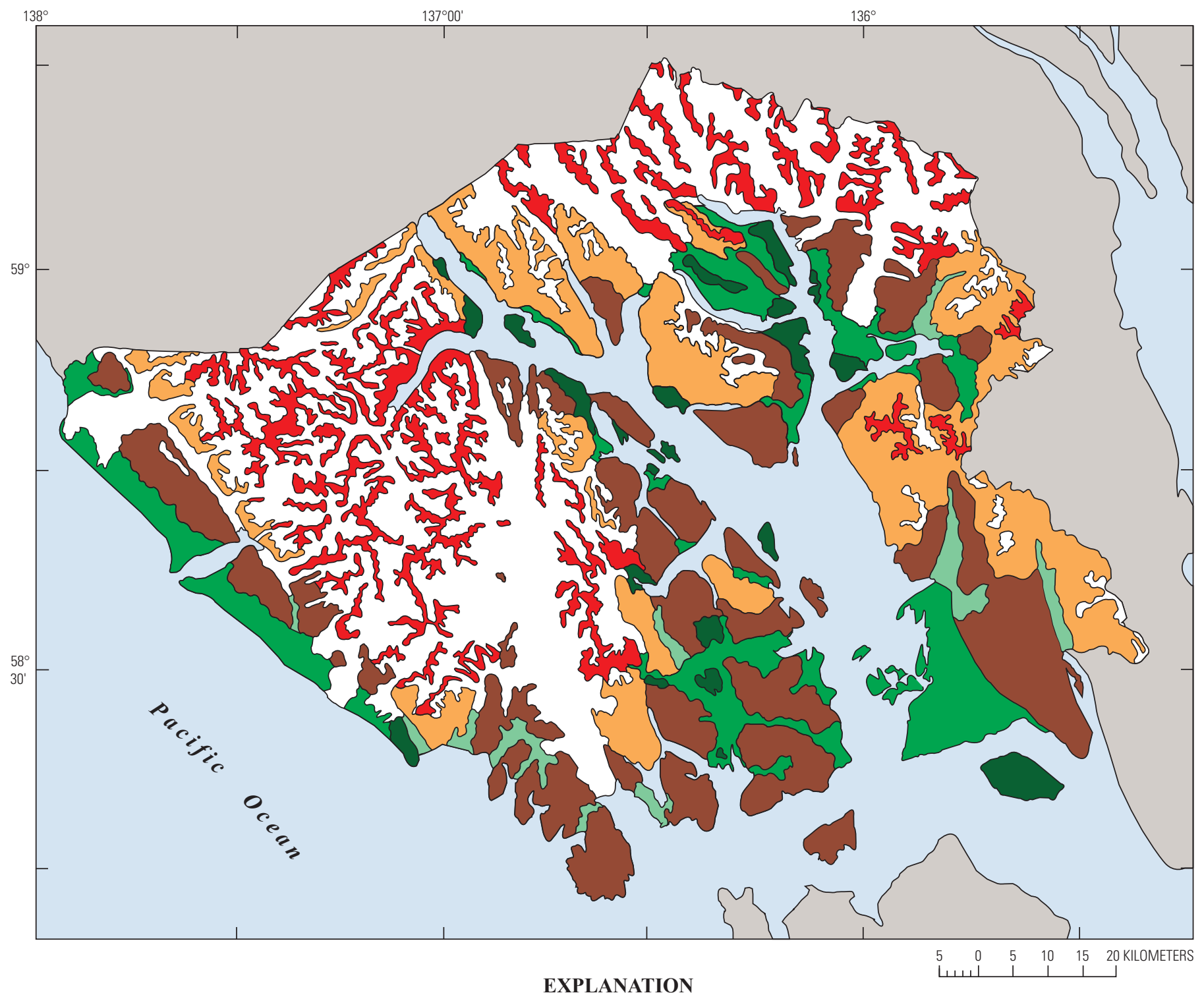

EXPLANATION

Icefields, glaciers, and permanent snowfields; some of which surround the narrow angular mountains, peaks, aretes, and steep slopes between glaciers that belong to the two units described immediately below

Mountain ridges, peaks, aretes, and lower bedrock rock slopes and walls that are surrounded by glaciers and permanent snowfields; includes some intervening ice-covered areas

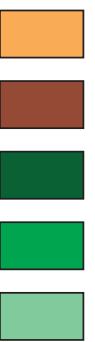

Angular mountains both with and without glaciers; generally not ice-dominated

Rounded mountains with few or no glaciers; maximum elevations above 2,000 feet

Hills and high plains; maximum elevations below 2,000 feet

Plains; includes uplifted marine terraces and outwash plains

Water or surficial-deposit-filled glacially eroded valleys

Figure 4. Map showing landform units in Glacier Bay National Park, southeast Alaska (see fig. 1 for location). Shorelines are not delineated on this map, but distinct freshwater and saltwater landforms exist none the less, essentially a narrow strip between lower low water and the upper limit of water effects, such as heavy spray, storm bench development, and shoreline creature habitat. 
Table 1. Glacier Bay National Park landtype-association analysis components, southeast Alaska.

\begin{tabular}{c}
\hline \multicolumn{1}{c}{ Bedrock geology } \\
\hline From USGS 1:250,000-scale bedrock-lithologic-unit map. \\
\hline $\begin{array}{c}\text { From inspection of topographic maps, Landsat, and side-looking } \\
\text { radar images. }\end{array}$ \\
\hline Storm zones and storm intensities \\
\hline $\begin{array}{c}\text { From anecdotal information and personal experience during the } \\
\text { months of May through September in 1966 and in 1975-1977. }\end{array}$ \\
\hline Glacier- and icefield-dominated microclimates \\
\hline $\begin{array}{c}\text { From general literature, personal experience, and inspection of } \\
\text { topographic maps. }\end{array}$ \\
\hline Climate and weather data \\
\hline $\begin{array}{c}\text { Only general information available; few sea-level and no high- } \\
\text { elevation stations. }\end{array}$ \\
\hline $\begin{array}{c}\text { No vegetation-community map exists for Glacier Bay, but a } \\
\text { Paige, 1971). }\end{array}$ \\
\hline
\end{tabular}

Table 2. Codes and brief descriptions of bedrock-lithologic units used in this report, Glacier Bay National Park, southeast Alaska.

\begin{tabular}{|c|c|}
\hline No. & Code-Description \\
\hline 1 & SC-Sedimentary-Carbonate \\
\hline 2 & SN-Sedimentary-Noncarbonate \\
\hline 3 & SQ_-Sedimentary-Quaternary \\
\hline 4 & SV-Sedimentary + Volcanic \\
\hline 5 & IV-Igneous-Volcanic/extrusive \\
\hline 6 & $\begin{array}{l}\text { IF-Igneous-Intrusive Felsic/Intermediate (high and inter- } \\
\text { mediate } \mathrm{SiO}_{2} \text { content) }\end{array}$ \\
\hline 7 & $\begin{array}{l}\text { IM-Igneous-Intrusive Mafic/Ultramafic (low and ex- } \\
\text { tremely low } \mathrm{SiO}_{2} \text { content) }\end{array}$ \\
\hline 8 & IQ_-Igneous-Quaternary Volcanic \\
\hline 9 & MC-Metamorphic-Metacarbonate \\
\hline 10 & $\begin{array}{l}\text { MP-Metamorphic-Meta-Noncarbonate-Metapelitic } \\
\text { (metamorphosed mud and silt) }\end{array}$ \\
\hline 11 & MV-Metamorphic-Meta-Noncarbonate-Metavolcanic \\
\hline 12 & $\begin{array}{l}\text { MI-Metamorphic-Meta-Noncarbonate-Metaintrusive/ } \\
\text { Plutonic }\end{array}$ \\
\hline 13 & $\begin{array}{l}\text { MU-Metamorphic-Undivided (includes metamorphosed } \\
\text { Noncarbonate rocks, mixed metamorphic (MV and MI) } \\
\text { and Igneous-Intrusive (IF) migmatite, and tectonically } \\
\text { mixed Sedimentary + Volcanic (SV) rock as melange }\end{array}$ \\
\hline
\end{tabular}

study produced polygons with consistent plant communities and ecological potentials. A follow-up study was conducted on northern Prince of Wales Island, southeast Alaska (fig. 1) by J.F. Baichtal, (USFS, oral comm., 1999) again using a bedrockgeologic map from a USGS study (Brew, 1996). This delineation approach was applied to all southeast Alaska to generate an ecological subsection map of the region (Nowacki and others, 2001).

These USFS studies resulted in the definition of the first 12 classes of the generalized bedrock-lithologic units classification scheme used in the GBNP (table 2; fig. 3). In the present study a class was added to the original 12 classes to cover Undivided Metamorphic Rocks that include migmatites and mixed metasedimentary and metavolcanic rocks (table 2). This thirteenth class was needed because (1) the pre-metamorphic nature of the rocks is not always well known, and (2) such rocks are abundant in GBNP, where they include the metamorphic analog of class 4 (Undivided Sedimentary plus Volcanic Rocks), as well as mixed metamorphic and granitic rocks.

The 69 bedrock units consist of the many lithologic types described by MacKevett and others (1971) and Brew (1997; unpub. data, 2004) in GBNP; they were coded and delineated on a copy of a 1:125,000-scale copy of the Brew (1997) geologic map. The units delineated are shown here at reduced scale (fig. 2). Information about the distribution of bedrock units in the Yakutat quadrangle part of the Park was acquired from G. Plafker (unpub. data, 2002) but is not included on the present generalized geologic map.

The studies on Kuiu Island and on northern Prince of Wales Island (fig. 1) described above were done in areas where the bedrock geology is relatively straightforward. The individual bedrock-geologic map units occur mostly in large continuous masses, and there are no glaciers (Brew and others, 1984; Brew, 1996). In contrast, the geology of most of GBNP is very complicated, and bedrock units occur in small outcrop areas. In addition, almost all of the area is heavily mantled with glaciers and permanent snowfields with the exception of the southeast and south-central portions of the Park; there the glaciers are fewer, bedrock units are more continuous, and the overall bedrock-plus-landform situation is more like that on Kuiu and northern Prince of Wales Islands.

The simplified classification of landforms used in this report originated from the USFS efforts to apply the Kuiu Island approach to all of southeast Alaska. That classification is given in table 3 and depicted on figure 4 . Class 2 of table 3 has been added to the landform classes in general use in southeast Alaska because many of the ice-dominated mountains have both habitat (for example, mountain goats) and an effect on the glaciers below (as a result of rockfall and other mass wasting). Class 7 of table 3 is not a landtype association, however, it is included to emphasize the significant and complex marine shoreline environment in GBNP. The shorelines border several different landform units and are underlain by a variety of bedrock-lithologic types. Shorelines, like icefields and glaciers, are not a landform strictly speaking, but further analysis 
Table 3. Codes and brief descriptions of the landform classification units used in this report, Glacier Bay National Park, southeast

Alaska.

\section{No. Code-Description}

1. I-Glaciers, icefields, and permanent snowfields, some of which surround the narrow angular mountains, peaks, arretes, and steep slopes between glaciers that belong to the two units described immediately below; boundaries are generalized; this class is not a landform, strictly speaking, flowing and stagnant ice are not differentiated.

2. M-Ice-dominated angular mountain ridges, peaks, arretes, and lower bedrock rock slopes and walls that are surrounded by glaciers and permanent snowfields; includes some intervening ice-covered areas; boundaries are generalized.

3. A-Non-ice-dominated angular mountains generally lacking glaciers.

4. R-Rounded mountains with few or no glaciers; maximum elevations above 2,000 feet.

5. H-Hills and high plains; maximum elevations below 2,000 feet.

6. P-Plains; includes uplifted marine terraces and outwash plains.

7. S-Shorelines, both of saltwater: essentially a narrow strip. between the marine ecosystem at lower low water and the upper limit of water-related effects, such as heavy spray, storm bench development, and shoreline-creatures.

may eventually result in their inclusion as parts of landtype phases that occur with more than one landtype association.

The landform types (and polygons) delineated in this study (fig. 4) are based on (1) visual inspection of USGS 1:250,000-scale topographic maps, and (2) the author's personal experience in the Glacier Bay region. This latter consists of the author having personally used all of the USGS 1:63,360-scale topographic series maps of the region on the ground in the field, and having repeatedly flown over almost every part of the Park during the course of the geologic mapping and other studies reported in MacKevett and others (1971), Brew and others (1978), and Brew (1997). The physiographic divisions proposed by Wahrhaftig (1964) were also considered in delineating the landform types used in this study.

This ecological mapping in GBNP involves overlaying and combining, preferably in a GIS environment, the bedrock-lithologic and landform data. Subject to evaluation for other factors, the resulting polygons can be used to form landtype associations and can be compared with other, especially vegetation, data for validation. The bedrock coding was applied to the geologic map (Brew, 1997), enabling the further amalgamation of adjacent like-coded generalized units into further-generalized bedrock-lithologic unit (BLU) polygons. Some generalization was required to fit the 1:125,000-scale geologic-map information onto the 1:250,000-scale topographic base map that was used for the delineation of icefields, glaciers, and all other landform units (LFUs). The LFUs and generalized BLUs have been digitized, but have been com- bined only by manually overlaying the corresponding maps for part of the Park. A combined symbol was used for the combined bedrock-lithologic-landform unit (BLFU) polygons. These BLFU polygons are tentatively proposed as ecosubsections for GBNP. Not including the shoreline "landform" type, there are 49 possible LFU plus BLU combinations available. Completion of the digitization, transfer into a GIS environment, and further efforts are planned.

The next effort on this project will be to compare the results of this landtype-association analysis with the ecologicsubsection information published by Nowacki and others (2001), and with any available vegetation-system maps. Once a landtype-association map has been completed and validated, the higher-level subsection boundaries should then be modified to conform to the boundaries of these finer-level ecological units.

\section{Discussion and Conclusions}

Systematic ecological mapping could provide the GBNP staff with a powerful tool for further research and interpretation. In particular, such mapping could further studies relating to climate change, successional changes of vegetation, and faunal environments, and to the interpretation of landscape evolution. Documenting the hierarchical ecological units would also allow managers, researchers, and interested visitors to better understand the larger ecological context of GBNP.

GBNP is an excellent place to use alternative ecosystem mapping procedures and to compare their results. With its ever-changing environment as the glaciers retreat and the vegetation and faunal assemblages change in response, the Park provides a unique opportunity for systematic longitudinal research studies of both terrestrial and marine ecosystems. This would require a long-term commitment to such studies on the part of both the National Park Service and its cooperating institutions. Such research studies could be the enduring focus of the Park's interpretative program as well as a significant contribution to the scientific understanding of these types of changes.

Two research studies could be initiated immediately. (1) The installation and maintenance of a series of remote weather stations at different elevations in different parts of the Park would provide the data needed for the analysis of the causes and effects of glacier movements and wasting. These stations would augment the shoreline stations that are already in place (G.P. Streveler, written commun., 2007). These remote weather stations should be at different elevations and on both sides of the Fairweather Range. The weather/climate factors to be analyzed could include, in the order of probable importance, temperature and precipitation, evaluation of the amount of cloud cover, wind direction and strength, and storm track patterns. It is likely that at least some of the stations would be destroyed regularly by storms and would have to be replaced. (2) A systematic effort to produce time-longitudinal 
plant- and animal-community maps of GBNP would provide a unique record of glacier-recession driven succession; without this information the interplay between the organic and non-organic factors cannot be fully understood. Efforts are already underway by J. Grunblatt of the National Park Service to document plant changes (G.P. Streveler, written comm., 2007). These research studies could be the basis of an integrated program that emphasizes ecosystems and their evolution, and thus provide an innovative basis for the GBNP interpretative program.

\section{References Cited}

Brew, D.A., compiler, 1996, Geologic map of the Craig, Dixon Entrance, and parts of the Ketchikan and Prince Rupert quadrangles, southeastern Alaska: U.S. Geological Survey Miscellaneous Field Investigations Series Map MF-2319, 53 p., 2 sheets, scale: 1:250,000.

Brew, D.A., 1997, Reconnaissance bedrock geologic map of Glacier Bay National Park, Alaska, in Glacier Bay Ecosystem GIS CDROM: U.S. Geological Survey, Biological Resources Division; scale 1:125,000; available from J. Geiselman, USDS/BRD, 1011 E. Tudor Road, Anchorage, AK 99503-6199.

Brew, D.A., 2000, Landforms + generalized bedrock-lithologic units in Glacier Bay National Park, southeastern Alaska: Are they a partial basis for eco(sub)system units? A study still in progress! (abs.): Geological Society of America, Abstracts with Programs, v. 32, no. 7, p. A-264.

Brew, D.A., Johnson, B.R., Grybeck, D., Griscom, A., Barnes, D.F., Kimball, A.L., Still, J.C., and Rataj, J.L., 1978, Mineral resources of Glacier Bay National Monument Wilderness Study Area, Alaska: U.S. Geological Survey Open-File Report 78-494, $670 \mathrm{p}$.

Brew, D.A., Ovenshine, A.T., Karl, S.M., and Hunt, S.J., 1984, Preliminary reconnaissance geologic map of the Petersburg and parts of the Port Alexander and Sumdum quadrangles, southeastern Alaska: U.S. Geological Survey Open-File Report 84-405, 43 p., 2 sheets, scale 1:250,000.

Cleland, D.T., Avers, P.E., McNab, W.H., Jensen, M.E., Bailey, R.G., King, T., and Russell, W.E., 1997, National hierarchical framework of ecological units, in Boyce, M.S., and Haney, A., eds., Ecosystem management: New Haven and London, Yale University Press, p. 181-200.

Labay, K.A., and Wilson F. H., 2004, World heritage site: Kluane/Wrangell-St. Elias/Glacier Bay/Tatshenshini-Alsek: U.S. Geological Survey Scientific Investigations Map 2819, 1 sheet, scale 1:750,000.
MacKevett, E.M., Jr., Brew, D.A., Hawley, C.C., Huff, L.C., and Smith, J.G., 1971, Mineral resources of Glacier Bay National Monument, Alaska: U.S. Geological Survey Professional Paper 632, 90 p.

Myers, M.D., Ayers, M.A., Baron, J.S., Beauchemin, P.R., Gallagher, K.Y., Goldhaber, M.B., Hutchison, D.R., LaBaugh, J.W., Sayre, J.W., Schwarzbach, S.E., Schwieg, E.S., Thormodsgard, J.S., van Wiper, C. III, and Wilde, W., 2007, USGS goals for the coming decade: Science, v. 318, 12 October 2007, p. 200-201.

Nowacki, G., Shephard, M., Krosse, P., Pawuk, W., Fisher, G., Baichtal, J., Brew, D.A., Kissinger, E., and Brock, T., 2001, Ecological subsections of southeast Alaska and neighboring areas of Canada: U.S. Department of Agriculture, Forest Service, Technical Publication No. R10-TP-75, 306 p., 1 map, scale I: 792,000.

Nowacki, G., Spencer, P., Fleming, M., Brock, T., and Jorgenson, T., 2002, Unified Ecoregions of Alaska: 2002: U.S. Geological Survey, Open-File Report 02-297, 1 map; digital files available at http://agdc.usgs.gov/data/projects/fhm. Service, Technical Publication No. R10-TP-75, 306 p., 1 map, scale I: 792,000.

Richter, D.H., Preller, C.C., Labay, K.A., and Shew, N.B., 2006, Geologic map of Wrangell-Saint Elias National Park, Alaska: U.S. Geological Survey Scientific Investigations Map SIM-2877, scale 1:500,000.

Shephard, M., and Brock, T., 2002, Landtype associations of the Yakutat Foreland: U,S, Department of Agriculture, Forest Service, Alaska Region Technical Publication No. R10-TP-109, 32 p.

Spencer, P., Nowacki, G., Fleming, M., Brock, T., and Jorgenson, T., 2002, Home is where the habitat is-An ecosystem foundation for wildlife distribution and behavior: Arctic Research of the United States, Interagency Arctic Research Policy Committee, v. 16, p. 6-17.

Streveler, G.P.. and Paige, B.B., 1971, The Natural history of Glacier Bay National Monument, Alaska, a survey of past research and suggestions for the future: U.S. National Park Service, $89 \mathrm{p}$.

U.S. Forest Service, 1996, Landforms of the Alaska RegionClassification Guide: U.S. Department of Agriculture Forest Service, Alaska Region, December 1996, 56 p.

Wahrhaftig, C., 1964, Physiographic divisions of Alaska: U.S. Geological Survey Professional Paper 482, 6 plates, $52 \mathrm{p}$ 


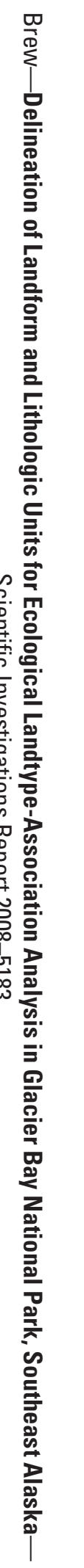

